\title{
Investigating the reduction of BTEX in automotive paint sludge combined with biological sludge by vermicomposting process using Eisenia fetida
}

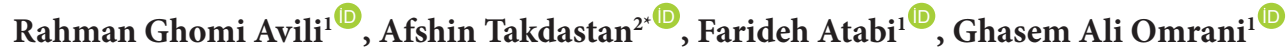 \\ ${ }^{1}$ Department of Natural Resources and Environment, Science and Research Branch, Islamic Azad University, Tehran, Iran \\ ${ }^{2}$ Environmental Technologies Research Center, Jundishapur University of Medical Sciences, Ahvaz, Iran
}

\begin{abstract}
Background: Due to the fact that in the process of car painting in the automotive industry, sludge containing dangerous compounds of benzene, toluene, ethylbenzene, xylene which cannot be released into the environment without purification, is inevitably produced, this study was conducted to investigate the feasibility of removing BTEX (benzene, toluene, ethylbenzene, and xylene) from the paint sludge of Saipa Automotive Company using Eisenia fetida worms.

Methods: This is an experimental study. First, mixtures with different proportions of sludge were prepared and loaded in suitable boxes. After preparing the desired sludge, their quantitative and qualitative characteristics were determined in terms of type and amount of BTEX, volatile materials, moisture content, and $\mathrm{C} / \mathrm{N}$ ratio. Then, to check the changes in BTEX, sampling was performed on different days during 90 days. BTEX measurements were performed using GC-MS method (NIOSH Method 1501).

Results: The results showed that in the best mixing ratio of sludge, the amount of benzene decreased from $3 \mathrm{mg}$ to less than $0.01 \mathrm{mg}$ in 30 days, toluene decreased from $1.5 \mathrm{mg}$ to zero over a 45 -day period, ethyl benzene was reduced from $7 \mathrm{mg}$ to zero $\mathrm{mg}$ over 70 days, and xylene decreased from $18 \mathrm{mg}$ to 0.9 mg over 90 days. In addition, in the same optimal mixing ratio, the amount of volatile organic matter, $\mathrm{pH}$, and $\mathrm{C} / \mathrm{N}$ ratio also had a decreasing trend in the vermicomposting process.

Conclusion: According to the results, E. fetida worms are able to work in mixed sludge and have the ability to break down BTEX.

Keywords: Benzene, Toluene, Ethylbenzene, Xylene, Sewage, Paint

Citation: Ghomi Avili R, Takdastan A, Atabi F, Omrani GA. Investigating the reduction of BTEX in automotive paint sludge combined with biological sludge by vermicomposting process using Eisenia fetida. Environmental Health Engineering and Management Journal 2021; 8(2): 87-94. doi: 10.34172/ EHEM.2021.12.
\end{abstract}

\author{
Article History: \\ Received: 21 November 2020 \\ Accepted: 21 February 2021 \\ ePublished: 14 May 2021
}

\section{Introduction}

One of the most important environmental aspects of the automotive industry is its paint sludge, the amount of which is very high. For example, in Saipa Automotive Company, which produces 1000 cars per day, about $3000 \mathrm{~kg}$ of paint sludge is produced. This sludge contains toxic mineral and organic substances such as benzene, toluene, ethylbenzene, and xylene known as BTEX, the direct discharge of which into the environment is dangerous for humans and the environment. Volatile organic compounds (VOCs) are low molecular weight hydrocarbons. An extremely important component of VOCs are BTEX compounds which contain benzene, toluene, ethylbenzene, o-xylene, and xylene isomers. BTEX hydrocarbons have a single loop aromatic structure that is caused by many natural processes or by human activities. BTEX has many applications in various industries such as oil, petrochemical, and automotive industries (1-3).

The US Environmental Protection Agency (EPA) and the US Food and Drug Administration (FDA) have identified benzene in the cancer group A1, which confirms its definitive carcinogenicity for humans (bone marrow and blood cancers). The EU has set the standard benzene concentration in open air at $5 \mu \mathrm{g} / \mathrm{m}^{3}$, the American Conference of Governmental Industrial Hygienists (ACGIH) considers time-weighted average (TWA) of exposure to benzene to be $0.5 \mathrm{ppm}$, and the US Department of Health and Safety has set the exposure limit to about $1 \mathrm{ppm}$. The ACGIH also states the TWA exposure to toluene and xylene to be 50 and $100 \mathrm{ppm}$, respectively, while Occupational Safety and Health Administration (OSHA) considers exposure levels of about 200 ppm 
for toluene and $100 \mathrm{ppm}$ for xylene. The ACGIH has classified toluene and xylene in the cancer group 3A, which confirms their potential for carcinogenicity and mutagenicity in humans or animals (4-7).

There are several methods, such as burning, encapsulating, stabilizing, and solidifying, etc. for removal of paint sludge, but removal of sludge contaminants by bioremediation is a flexible, inexpensive, and environmentally friendly method. In general, siliceous waste management involves physical, chemical, and biological methods. One of the biological processes (bioremediation) is fertilization and preparation of compost and vermicompost. Vermicompost is the result of a semi-aerobic process with about $80 \%$ moisture, which is carried out by a specific species of insects, fungi, bacteria, and actinomycetes. The types of earthworms that are commonly involved in the process of stabilizing organic wastes include: Eisenia fetida or red worm or compost worm, Dendrobaena veneta, Lumbricus rubellus, and Lumbricus terrestris (8-11). On the other hand, one of the problems of large refineries such as refineries in the automotive industry is the existence of a large amount of biological sludge, which is a good environment for growing E. fetida worms to produce vermicompost. Today, the use of biological sludge bed for the reproduction of worms has been studied and done in several cases. In the process of producing a composite of sewage sludge, earthworms are used as biological agents for the stabilization of organic matter. Since sewage sludge contains a large amount of organic and nutritious materials, it can be used as a suitable nutrient for feeding worms in the process of producing vermicompost $(12,13)$.

Eisenia fetida is the most widely used worm in the vermicompost production. These worms are extraordinary worms, which are mostly used in the production of fertilizers from waste. Red worms endure different environmental conditions. There is no limit to the amount of the fertilizer and the number of worms. Their population is proportional to available food. Factors affecting the production of fertilizers by vermicompost with E. fetida include temperature, humidity, $\mathrm{C} / \mathrm{N}$ ratio, $\mathrm{pH}$, oxygen content, particle size, the content of volatile solids, and soil surface density $(14,15)$.

Numerous studies have been conducted that show the ability of some types of earthworms to purify environmental pollutants such as heavy metals and a variety of organic matter. One of the most widely used species is E. fetida. Schaefer and Juliane reported that earthworms can activate the decomposition process of petroleum compounds in the vermicomposting process, therefore, they can be used in refining contaminated soils with medium concentrations $(<4000 \mathrm{mg} / \mathrm{kg})$ for total petroleum hydrocarbon (TPH). They also reported that the rate of decomposition of oil compounds depends on the species of earthworms. Schaefer and Juliane showed that increasing the catabolic activity caused by the presence of E. fetida resulted in the removal of $91 \%$ of hydrocarbon compounds with an infection concentration of $1074 \mathrm{mg} /$ $\mathrm{kg}$ in 56 days of biological treatment by vermicompost along with biological wastes (16). The study of Takdastan et al on the biocomposting process of biological sewage sludge with the aim of regulating and neutralizing the risk of drilling in Khuzestan oilfield showed that the amount of TPH in excavation logs in Ahvaz oilfield is $42.004 \mathrm{~g} / \mathrm{kg}$, and in the course of 2 months of biocomposting process combined with biological sludge reached a concentration of $18.77 \mathrm{~g} / \mathrm{kg}$ at a proportion of 1 to 1 . According to the literature, sludge contaminated with toxic chemicals and other chemical compounds have been treated with worms, and these worms can reduce many toxic organic pollutants through the biological process of vermicomposting (17).

On the other hand, the growing number of cars in the country brings about the production of more industrial wastes such as sludge. Considering that BTEX compounds are an important part of the car paint sludge which have their own health hazards, careful measures should be taken for the management of these dangerous compounds. An analysis of the solvents used in the paint shops of the automotive industry shows that VOCs such as xylene, ethylbenzene, benzene, and toluene have the highest percentage in diluent thinner. A part of this VOC is directly introduced into the air and the rest enters the sludge. Based on this view, this research was done (18).

\section{Materials and Methods}

This is a pilot-scale experimental study (19). For this research, both samples of paint sludge and biological sludge were prepared from Saipa Automotive Company. Then, these samples were mixed with the ratios mentioned in a roofed warehouse with suitable temperature and humidity conditions. As this study was conducted in autumn and winter 2018 in the northern region of Iran, the temperature was set in the range of 18 to $25^{\circ} \mathrm{C}$ by a gas heater and water was sprayed to regulate humidity. Table 1 shows the mixing percentage of sludge (amount of paint sludge and biological sludge) in 27 samples. Based on similar articles in this study, 500 E. fetida worms were dispersed inside each box. A very small net was used to prevent the worms from escaping inside the boxes.

The number of worms was counted on days 1, 15, 30, 50,70 , and 90 . In the optimal mixing ratio, the number of E. fetida worms increased from 500 in the first day to 980 on day 90 . This suggests that E. fetida worms, with the help of microorganisms in biological sludge, are able to grow and reproduce increasingly in a mixed sludge environment contaminated with BTEX. Pilots F and G had the highest proliferation of worms and growth and activity of microorganisms. And, in pilots A, B, and C, the worms often disappeared. This is due to the threshold of tolerance of worms to sludge contaminants such as BTEX.

The sludge mixture was rotated for aeration three days per week in each pilot after starting the vermicomposting 
process. The time of vermicompost of paint sludge with biological sludge in all mixes was 90 days. The $\mathrm{C} / \mathrm{N}$ ratio was low at the beginning of the vermicomposting process. Horticultural waste and straw were used to increase and adjust the $\mathrm{C} / \mathrm{N}$ ratio within the range of 25 to 30 .

Then, sampling was done at specified times. Random sampling from each box (three 25 -g samples from each box with a diameter of less than $2 \mathrm{~mm}$ ) was done using quadruple method on days 1, 15, 30, 50, 70, and 90 . During the decomposition process, in addition to BTEX, the amount of heavy metals, $\mathrm{pH}$, moisture content, the content of solids in sludge, $\mathrm{C} / \mathrm{N}$ ratio, and temperature were also measured. BTEX was measured by GC-MS (NIOSH Method 1501). Different parameters such as humidity, organic nitrogen, organic carbon, dry solids, volatile and fixed solids, and $\mathrm{pH}$ were measured using standard methods (20-23). BTEX was measured in a trusted laboratory of the Environmental Protection Agency called Arman Mohit Pak Iranian. At specified times, 25 $\mathrm{g}$ of sample from each box was transferred to a trusted laboratory of the Environmental Protection Agency (Arman Mohit Pak Iranian) for BTEX measurement. The samples were analyzed after preparation of a gas chromatograph equipped with a flame ionization detector (FID) system. To determine the amount of BTEX, Agilent GC model 6890 made in USA with HP-5MS-5\% phenyl silox column was used (mass spectrometer).

\section{Results}

The characteristics of the sludges used and their mixtures are given in Tables 2 and 3. Table 4 also shows the amount of BTEX in the Saipa paint sludge. Table 5 shows the reduction trend of BTEX in different pilots during 90 days.

\section{The rate of change of the $C / N$ ratio in vermicompost}

Adjusting the $\mathrm{C} / \mathrm{N}$ ratio is a critical factor in performing the composting and vermicomposting processes. Therefore, if its ratio is high in the mixed sample, its ratio should be reduced with substances such as sewage sludge and urine; and if its ratio is low, it should be increased with substances such as straw and other cellulosic materials. Due to the low $\mathrm{C} / \mathrm{N}$ ratio of the prototypes tested in this study, the amount of $\mathrm{C} / \mathrm{N}$ ratio was increased to about 27 with sawdust $(24,25)$. The changes in the $\mathrm{C} / \mathrm{N}$ ratio is shown in Figure 1. As shown in this figure, in all sludge mix treatments, the $\mathrm{C} / \mathrm{N}$ ratio decreased during the study period (90 days). While in the three pilots $\mathrm{A}, \mathrm{B}$, and $\mathrm{C}$ with low biological sludge, the $\mathrm{C} / \mathrm{N}$ ratio on day 90 was 23.2, 22.5, and 18.8, respectively, in the three pilots E, F, and G with the highest level of biological sludge, the $\mathrm{C} / \mathrm{N}$ ratio decreased to $14.8,14.3$, and 13.5 , respectively.
The decomposition of organic matter is generally done by microorganisms, especially bacteria, in the presence of worms. As shown in Figure 1, the initial $\mathrm{C} / \mathrm{N}$ ratio in the seven pilots $A, B, C, F, E, D$, and G were 25.6, 26.7, $24.8,27.2,26.3,27$, and 27.9, respectively. At the end of the process, the $\mathrm{C} / \mathrm{N}$ ratio in pilot $\mathrm{A}, \mathrm{B}$, and $\mathrm{C}$ with the lowest biological sludge, it reached 23.2, 22.5, and 18.8, respectively. And in the three pilots E, F, and G with the highest amount of biological sludge, the $\mathrm{C} / \mathrm{N}$ ratio

Table 1. Characteristics of the pilots of vermicompost mixed sludge

\begin{tabular}{lccc}
\hline Pilot & $\begin{array}{c}\text { The amount of } \\
\text { biological sludge } \mathbf{( k g )}\end{array}$ & $\begin{array}{c}\text { The amount of } \\
\text { paint sludge } \mathbf{( k g )}\end{array}$ & $\begin{array}{c}\text { The number of } \\
\text { pilot boxes }\end{array}$ \\
\hline A & $6 \pm 0.1$ & $6 \pm 0.1$ & 3 \\
\hline B & $6 \pm 0.1$ & $3 \pm 0.1$ & 3 \\
\hline C & $6 \pm 0.1$ & $1.5 \pm 0.1$ & 3 \\
\hline D & $6 \pm 0.1$ & $1 \pm 0.1$ & 3 \\
\hline E & $6 \pm 0.1$ & $0.750 \pm 0.01$ & 3 \\
\hline F & $6 \pm 0.1$ & $0.600 \pm 0.01$ & 3 \\
\hline G & $6 \pm 0.1$ & $0.375 \pm 0.01$ & 3 \\
\hline M & - & $6 \pm 0.1$ & 3 \\
\hline$N$ & - & $6 \pm 0.1$ & 3 \\
\hline
\end{tabular}

Table 2. Characteristics of the sludge used

\begin{tabular}{lcc}
\hline Parameter & Paint sludge + SD & Biological sludge + SD \\
\hline $\mathrm{pH}$ & $8.3 \pm 0.1$ & $6.7 \pm 0.1$ \\
\hline Humidity (\%) & $21 \pm 1.7$ & $64 \pm 3$ \\
\hline Dry solids (\%) & $79 \pm 2.6$ & $36 \pm 1.5$ \\
\hline Volatile solids (\%) & $73 \pm 3.65$ & $87 \pm 3.9$ \\
\hline Fixed solids (\%) & $27 \pm 1.2$ & $23 \pm 1.1$ \\
\hline Nitrogen $(\mathrm{mg} / \mathrm{kg})$ & $464 \pm 11.3$ & $3.7 \pm 0.1$ \\
\hline Carbon $(\mathrm{mg} / \mathrm{kg})$ & $35000 \pm 36$ & $16.2 \pm 0.3$ \\
\hline C/N ratio & $74 \pm 1.3$ & $16.6 \pm 0.2$ \\
\hline
\end{tabular}

Table 3. The $\mathrm{C} / \mathrm{N}$ ratio of sludge samples used

\begin{tabular}{lccc}
\hline Treatment & Organic Carbon & Nitrogen & C/N \\
\hline $6 \mathrm{~kg} / 6 \mathrm{~kg}$ & 30.92 & 3.962 & $7.81 \pm 0.1$ \\
\hline $6 \mathrm{~kg} / 3 \mathrm{~kg}$ & 29.71 & 3.95 & $7.52 \pm 0.1$ \\
\hline $6 \mathrm{~kg} / 1.5 \mathrm{~kg}$ & 28.19 & 3.8 & $7.22 \pm 0.1$ \\
\hline $6 \mathrm{~kg} / 1 \mathrm{~kg}$ & 26.21 & 3.81 & $6.92 \pm 0.1$ \\
\hline $6 \mathrm{~kg} / 750 \mathrm{~g}$ & 23.62 & 3.76 & $6.33 \pm 0.1$ \\
\hline $6 \mathrm{~kg} / 600 \mathrm{~g}$ & 22.93 & 3.7 & $6.25 \pm 0.1$ \\
\hline $6 \mathrm{~kg} / 375 \mathrm{~g}$ & 21.61 & 3.61 & $6.01 \pm 0.1$ \\
\hline Biological sludge & 19.81 & 3.51 & $5.65 \pm 0.1$ \\
\hline Pain sludge & 35.11 & 0.464 & $75.55 \pm 0.1$ \\
\hline
\end{tabular}

Table 4. The amount of BTEX in the paint sludge

\begin{tabular}{lcccc}
\hline BTEX Type & Xylene & Ethylbenzene & Toluene & Benzene \\
\hline The Amount of BTEX+ SD $(\mathrm{mg} / \mathrm{kg})$ & $151 \pm 6.54$ & $65 \pm 2.21$ & $12.6 \pm 0.7$ & $23.5 \pm 1.01$ \\
\hline
\end{tabular}


Table 5. BTEX removal rate in different samples $(\mathrm{mg} / \mathrm{kg})$

\begin{tabular}{|c|c|c|c|c|c|c|}
\hline \multirow{2}{*}{ Pilot } & \multicolumn{6}{|c|}{ Time } \\
\hline & Day 1 & Day 15 & Day 30 & Day 50 & Day 70 & Day 90 \\
\hline A & $252.1 \pm 5.4$ & $244 \pm 5.2$ & $235 \pm 4.6$ & $226 \pm 4.4$ & $216 \pm 4.2$ & $199 \pm 4.1$ \\
\hline B & $137 \pm 1.7$ & $130 \pm 1.6$ & $120 \pm 1.4$ & $181 \pm 1.6$ & $101 \pm 0.9$ & $86 \pm 0.9$ \\
\hline C & $91 \pm 0.9$ & $82.5 \pm 0.6$ & $78.5 \pm 0.4$ & $71 \pm 0.4$ & $61 \pm 0.2$ & $50.8 \pm 0.1$ \\
\hline $\mathrm{D}$ & $64 \pm 0.9$ & $59.8 \pm 0.7$ & $53.4 \pm 0.7$ & $45.8 \pm 0.5$ & $38.4 \pm 0.4$ & $32 \pm 0.3$ \\
\hline$E$ & $46 \pm 0.6$ & $40.8 \pm 0.5$ & $36.4 \pm 0.4$ & $31.6 \pm 0.3$ & $21.8 \pm 0.2$ & $17.9 \pm 0.2$ \\
\hline $\mathrm{F}$ & $29.5 \pm 0.4$ & $22.6 \pm 0.3$ & $17.91 \pm 0.2$ & $11.5 \pm 0.1$ & $6 \pm 0.05$ & $8 \pm 0.01 .0$ \\
\hline G & $17 \pm 0.2$ & $12.9 \pm 0.9$ & $6.91 \pm .05$ & $4.9 \pm 0.05$ & $1 \pm 0.01$ & $5 \pm 0.01 .0$ \\
\hline
\end{tabular}

decreased to $14.8,14.3$, and 13.5 , respectively. In other words, due to the high degradation of organic matter in pilots $\mathrm{F}$ and $\mathrm{G}$, their carbon consumption was higher than samples in pilots $\mathrm{A}$ and $\mathrm{B}$, therefore, the $\mathrm{C} / \mathrm{N}$ ratio in these active samples decreased more.

pH changes in the vermicompost samples of mixed sludge As can be seen in Figure 2, the $\mathrm{pH}$ of the mixed samples was initially alkaline, which reached a neutral level after the activity of the biological mass. Similar studies have suggested an optimal $\mathrm{pH}$ for the vermicompost activity to be 6 to 9. The main reason for the decrease in $\mathrm{pH}$ is the decomposition of organic matter by worms and bacteria and the production of $\mathrm{CO}_{2}$ and the formation of intermediate acids $(26,27)$.

Changes in the percentage of volatile solids in the vermicompost

Table 6 also shows the trend of significant reduction of VOCs, especially in samples in which the activity of worms and bacteria was higher. The optimum sludge mixing ratio of VOCs decreased from $80.4 \%$ to $37 \%$.

The decomposition process of volatile organic solids in different pilots is shown in Table 6. The observation of the decomposition process in 90 days showed that the changes in the percentage of organic solids for the pilots, especially two pilots $\mathrm{F}$ and $\mathrm{G}$, had a decreasing trend. In three pilots with low mixing of biological sludge including pilots $\mathrm{A}, \mathrm{B}$, and $\mathrm{C}$, the amount of organic matter decreased from $60.6,65$, and 72.8 to 53,49 , and 42.4 , respectively (a slight decrease). The main reason for which is very low biodegradation. It has been caused by microorganisms, possibly due to the escape of VOCs or BTEX in the paint sludge. The highest reduction of volatile organic matter occurred in pilots $\mathrm{F}$ and $\mathrm{G}$; therefore, the highest reduction of BTEX occurred in the same pilots. This is due to the increased activity of bacteria, microorganisms, and worms in the biological sludge of wastewater, which increased the rate of decomposition and removal of organic matter. The increased growth of microorganisms and greater mobility of worms eventually led to further decomposition of organic solids and BTEX in the vermicompost. Bacteria, microorganisms, and worms, by feeding on organic matter in biologic sludge reduced them in the masses. As a result, it can be concluded that measuring the changes in the organic solids index is very important for this study because it shows the decomposition and removal of BTEX well (28).

\section{Changes in BTEX in vermicompost samples}

Figures 3 to 6 show the amount of BTEX in the bulk of vermicompost of mixed sludge. In the tested dye sludge, the amount of benzene, toluene, ethylbenzene, and xylene was reported as $23.5,12.6,65$, and $151 \mathrm{mg} / \mathrm{kg}$, respectively. As shown in Figures 3 to 6, in all sludge treatments, the amount of BTEX decreased during vermicomposting process. Due to the presence of a set of microorganisms, especially heterotrophic bacteria, biological sewage

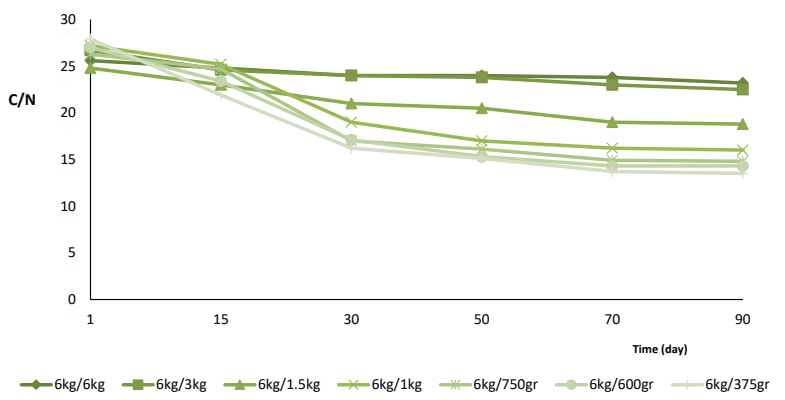

Figure 1. Changes in the $\mathrm{C} / \mathrm{N}$ ratio in the vermicompost samples during destruction period.

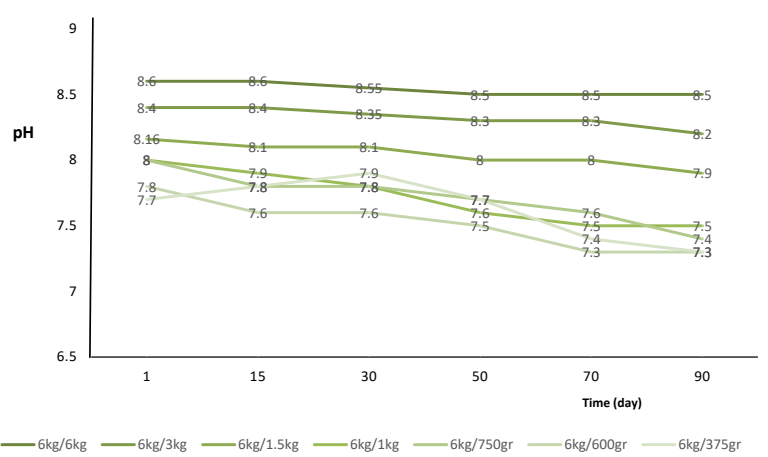

Figure 2. $\mathrm{pH}$ changes in the vermicompost samples during destruction period. 
Table 6. Variation in the percentage of volatile solids in pilots during degradation period $(\mathrm{mg} / \mathrm{kg})$

\begin{tabular}{|c|c|c|c|c|c|c|}
\hline \multirow{2}{*}{ Pilot } & \multicolumn{6}{|c|}{ Date (day) } \\
\hline & Day 1 & Day 15 & Day 30 & Day 50 & Day 70 & Day 90 \\
\hline $6 \mathrm{~kg} / 6 \mathrm{~kg}-\mathrm{A}$ & 60.5 & 58 & 56 & 54 & 54 & 54 \\
\hline $6 \mathrm{~kg} / 3 \mathrm{~kg}-\mathrm{B}$ & 66 & 62 & 59 & 52 & 50 & 49.9 \\
\hline $6 \mathrm{~kg} / 1.5 \mathrm{~kg}-\mathrm{C}$ & 73.8 & 65 & 61.5 & 53 & 44 & 42.9 \\
\hline $6 \mathrm{~kg} / 1 \mathrm{~kg}-\mathrm{D}$ & 76 & 65.8 & 59.5 & 52.6 & 44 & 41 \\
\hline $6 \mathrm{~kg} / 750 \mathrm{~g}-\mathrm{E}$ & 79.3 & 66 & 57 & 52 & 42 & 40.2 \\
\hline $6 \mathrm{~kg} / 600 \mathrm{~g}-\mathrm{F}$ & 80.5 & 66.5 & 54.8 & 50 & 38.9 & 36 \\
\hline 6 kg/375 g-G & 86.5 & 68.5 & 52 & 44.6 & 37 & 35.5 \\
\hline
\end{tabular}

sludge has a very high potential for the decomposition of organic matters such as BTEX, which is considerably increased by the presence of E. fetida worms (29). According to the results of this study, E. fetida worms, along with microorganisms in the biological sludge, are able to function well and refine the pollutants when the proportion of the paint sludge to the biological sludge is 1 to 6 . However, the best results were obtained when this ratio was 1 to 10 , as shown by the figures. At this ratio, BTEX in the paint sludge was significantly degraded and reduced during the period from 30 to 90 days.

The total BTEX concentration in the paint sludge of Saipa was about $252.1 \mathrm{mg} / \mathrm{kg}$, which was reduced due to mixing with biological sludge in the samples. For example, in sample F on the first day, BTEX was $29.5 \mathrm{mg} / \mathrm{kg}$, which was completely decomposed on the 90th day. In pilots A, $\mathrm{B}$, and $\mathrm{C}$, the BTEX reduction was not significant due to the presence of a high proportion of paint sludge to the biological sludge of the treatment plant. However, in pilots $\mathrm{E}, \mathrm{F}$, and $\mathrm{G}$, due to the mixing of more biological sludge with paint sludge and the lower initial BTEX, despite the combination of vermicompost worms and microorganisms, especially heterotrophic bacteria, the BTEX volume significantly degraded and reduced on day 90. As shown in Figures 3 to 6, it can be stated that the BTEX ratio of the samples in each of the pilots A, B, C, F, E, D, and G decreased from day one to day 90 , but the highest reduction of BTEX occurred in pilot $G$ (at the mixing ratio of $6 \mathrm{~kg}$ of biological sludge with $600 \mathrm{gr}$ of paint sludge, i.e, the ratio of 10 to 1 ). At this ratio, benzene decreased from $3 \mathrm{mg}$ to $0.01 \mathrm{mg}$. Toluene reached $1.5 \mathrm{mg}$ over a period of 45 days. Ethylbenzene ranged from $7 \mathrm{mg}$ to about zero over a period of 60 days, and xylene, over 90 days, ranged from 18 to about $0.9 \mathrm{mg}$ (30-32).

\section{Discussion}

This study showed that BTEX was significantly reduced during the mixed sludge vermicomposting process. Therefore, in general, the results of this study are consistent with the results of other similar studies (33-40). However, the results of this study have some differences with those of some previous studies according to the method of work, bed characteristics, sludge type, treatment method, test conditions, study time, number and characteristics of earthworms and bed microorganisms.

Hosseini Panah and Takdastan concluded that the ratio of 2:1 mixing of oil-based drilling mounds with sludge biological vermicomposting has the highest TPHs decomposition efficiency compared to other percentages of waste mixing over a period of 60 days in this study (34). Amouei et al also reported that hazardous compounds such as heavy metals were significantly reduced by the composting process on soil in the North of Iran (35). Opuada Ameh et al also investigated the effect of earthworms (Eudrilus eugeniae) on the removal of organic

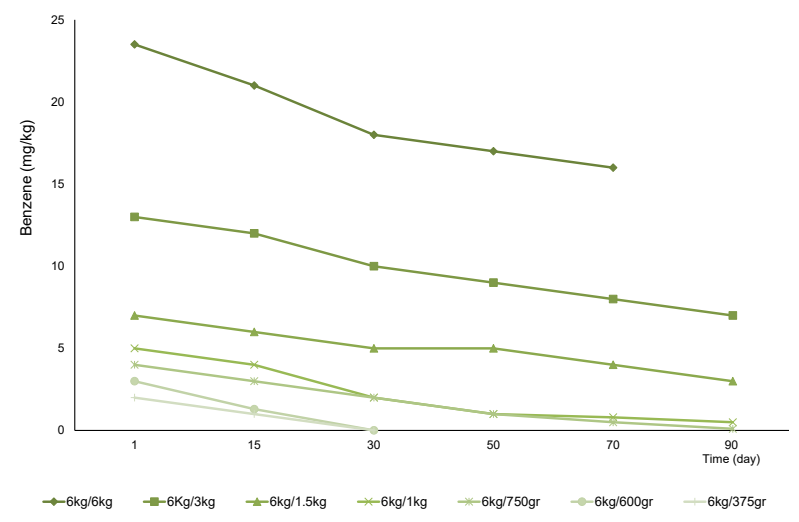

Figure 3. Variations of benzene concentration throughout the degradation time $(\mathrm{mg} / \mathrm{kg})$.

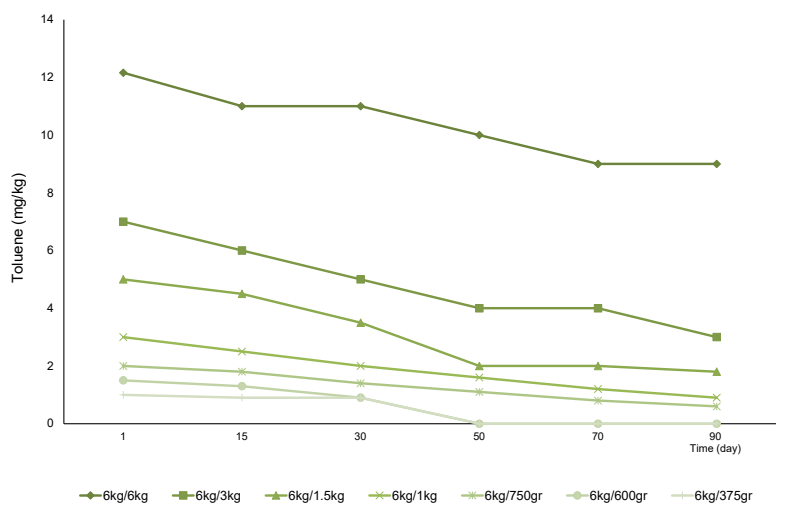

Figure 4. Variations of toluene concentration throughout the degradation time $(\mathrm{mg} / \mathrm{kg})$. 


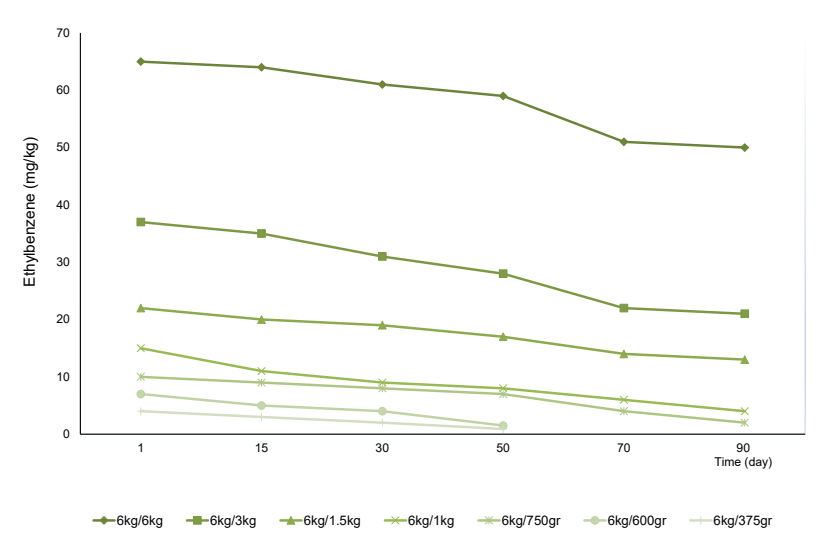

Figure 5. Variations of ethylbenzene concentration throughout the degradation time $(\mathrm{mg} / \mathrm{kg})$.

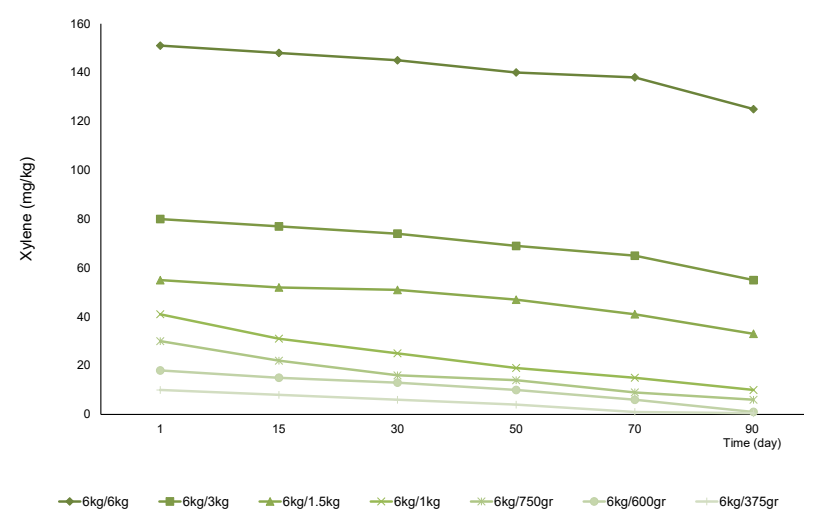

Figure 6. Variations of xylene concentration throughout the degradation time $(\mathrm{mg} / \mathrm{kg})$.

compounds in engine oil. They found that the rate of biodegradation of the pollutant increased with increasing the initial motor oil concentration. The concentration of engine oil used per kilogram of soil was 5, 10, 15, and 20 $\mathrm{g}$, respectively, and the rate of reduction of hydrocarbon engine oil due to biodegradation with the earthworms was $16.91 \%, 20.82 \%, 34.68 \%$, and $36.28 \%$, respectively (36). Using 1000 earthworms (E. fetida) in hydrocarboncontaminated soil, a study showed that not only the worms tolerated the toxic environment and survive, but they also significantly reduced toxic hydrocarbons. The hydrocarbons C10-C14 were reduced by $99.9 \%$, the C15C28 by $99.8 \%$, and the C29-C36 by $99.7 \%$ by earthworms (37).

As the aim of this study was to investigate the removal of BTEX from the paint sludge of the automotive industry. This type of sludge in addition to BTEX also has other toxic substances, so compared to the mentioned studies, BTEX decreased in pilots when the larger volumes of biological sludge were mixed. In other words, this study showed that biological wastewater sludge with a ratio of 10 volumes along with paint sludge with a ratio of one volume, the best BTEX removal efficiency occurs compared to other mixtures over a period of 90 days.
In fact, worms are unable to survive in large quantities in paint sludge environments and can only survive and reduce organic pollutants such as BTEX if they contain ten times the volume of biological sludge. Compared to similar studies on reducing BTEX paint sludge in the automotive industry, the time of the present research was longer and the amount of biological sludge required was higher. And it was revealed that earthworms in paint sludge are able to grow and reproduce as long as the level of contamination is not too high.

\section{Conclusion}

In this study, the rate of BTEX reduction of paint sludge in the automotive industry was investigated by the vermicomposting process mixed in different proportions with biological sludge from a wastewater treatment plant. Analysis of the results showed that the highest amount of BTEX removal occurs by mixing $6 \mathrm{~kg}$ of biological sludge with $600 \mathrm{~g}$ of paint sludge. That is, at the ratio of 10 to 1 BTEX, at which the sludge of Saipa Automotive Industries decreased significantly in 30 to 90 days. At this ratio, benzene mixture was reduced from $3 \mathrm{mg}$ to less than $0.01 \mathrm{mg}$ in 30 days while its volatility was $36 \%$. Toluene decreased from $1.5 \mathrm{mg}$ to zero over a 45 -day period while its volatility rate was $30 \%$. Ethyl benzene decreased from $7 \mathrm{mg}$ to about zero in 60 days while its volatility rate was $23 \%$. And xylene decreased from $18 \mathrm{mg}$ to about 0.9 in 90 days while its volatility was $17 \%$. At the same mixing ratio, the $\mathrm{C} / \mathrm{N}$ ratio decreased from 27 on the first day to 13.5 on the 90 th day. The amount of volatile solids or organic matter in the mass also decreased significantly. Therefore, it was found that E. fetida worm, along with microorganisms in biological sludge, is able to work in mixed sludge and has a very high ability to remove BTEX.
Acknowledgments
Professor Ghasem Ali Omrani is certainly known as the father of Iranian waste management science due to his efforts in the field of waste for many years. He is one of the first Iranian graduated student in the field of environmental engineering in Germany, who returned to Iran after gaining a lot of experience in the field of waste management and implemented many aspects of waste management for the first time in Iran. For about half a century, he has been a professor at the Faculty of Health of Tehran University of Medical Sciences and the Faculty of Natural Resources and Environment at Tehran University of Science and Research. Many professors in Iranian universities have been his students. All those who have benefited from the presence of this great master will certainly acknowledge the sincerity of his behavior and compassionate efforts for all students. He has authored numerous articles and books in the field of waste. This article has been done with the efforts and guidance of this great master during his lifetime, so the authors appreciate him and wish him rest in peace. 
This paper is a part of Ph.D. thesis of Rahman Ghomi Avili and its financial support was provided by Science and Research Branch, Islamic Azad University, Tehran, Iran.

\section{Ethical issues}

The authors certify that all data collected during the study are as presented in this manuscript, and no data from the study has been or will be published elsewhere separately.

\section{Conflict of interests}

The authors declare that they have no conflict of interests.

\section{Authors' contributions}

All authors have participated in the study design, literature search, writing of the manuscript, and data collection, analysis, and interpretation. All authors carefully reviewed, refined, and approved the manuscript.

\section{References}

1. Rene ER, Mohammad BT, Veiga MC, Kennes C. Biodegradation of BTEX in a fungal biofilter: Influence of operational parameters, effect of shock-loads and substrate stratification. Bioresource Technology 2012; 116: 204-13. doi: 10.1016/j. biortech.2011.12.006.

2. Wang YY, Zheng SW, Gao D, Cai L. The organic degradation and potential microbial function in a 15-day sewage sludge biodrying. Compost Science \& Utilization 2020; 28(1): 4957. doi: 10.1080/1065657X.2020.1749183.

3. Fooladi M, Moogouei R, Jozi SA, Golbabaei F, Tajadod G. Phytoremediation of BTEX from indoor air by Hyrcanian plants. Environmental Health Engineering and Management Journal. 2019;6(4):233-40. doi:10.15171/ EHEM.2019.26

4. United States Environmental Protection Agency. Standards for the Use or Disposal of Sewage Sludge (40 CFR Part 503). [cited 2020 Oct 12] Available from: https://www.epa.gov/ biosolids/biosolids-laws-and-regulations\#standards.

5. Rojas-Avelizapa N, Olvera-Barrera E, Fernández-Linares L. Feasibility study of bioremediation of a drillingwaste-polluted soil: stimulation of microbial activities and hydrocarbon removal. J Environ Sci Health A Tox Hazard Subst Environ Eng 2005; 40(12): 2189-201. doi: 10.1080/10934520500234692.

6. Margesin R, Schinner F. Biodegradation and bioremediation of hydrocarbons in extreme environments. Appl Microbiol Biotechnol 2001; 56(5-6): 650-63. doi: 10.1007/ s002530100701.

7. Simantiraki F, Kollias CG, Maratos D. Hahladakis J. Gidarakos E. Qualitative determination and application of sewage sludge and municipal solid waste compost for BTEX removal from groundwater. Journal of Environmental Chemical Engineering 2013; 1(1-2): 9-17. doi: 10.1016/j. jece.2013.02.002.

8. Contreras-Ramos SM, Álvarez-Bernal D, Dendooven L. Characteristics of earthworms (Eisenia fetida) in PAHs contaminated soil amended with sewage sludge or vermicompost. Applied Soil Ecology 2009; 41(3): 269-79. doi: 10.1016/j.apsoil.2008.11.008.
9. Feizi R, Jorfi S, Takdastan A. Bioremediation of phenanthrene-polluted soil using Bacillus kochii AHVKH14 as a halo-tolerant strain isolated from compost. Environmental Health Engineering and Management Journal. 2020;7(1):23-30. doi:10.34172/EHEM.2020.04

10. Mostafaii GR, Aseman E, Asgharnia H, Akbari H, Iranshahi L, Sayyaf H. Efficiency of the earthworm Eisenia fetida under the effect of organic matter for bioremediation of soils contaminated with cadmium and chromium. Brazilian Journal of Chemical Engineering 2016; 33(4): 827-34. doi: 10.1590/0104-6632.20160334s20150230.

11. Yousefi Z, Amouei AI, Asgharnia H, Nemati A, Vaezzadeh M. Compost production from household solid wastes by earthworms. Journal of Babol University of Medical Sciences 2011; 14(1): 30-5. [In Persian].

12. Abbiramy KS, Ronald Ross P, Joothi P. Validation of tropical artificial soil by chronic toxicity studies on eisenia fetida against superphosphate. International Letters of Natural Sciences 2014; 13: 31-40. doi: 10.18052/www.scipress.com/ ILNS.13.31.

13. Ludibeth SM, Marina IE, Vicenta EM. Vermicomposting of sewage sludge: earthworm population and agronomic advantages. Compost Science \& Utilization 2012; 20(1): 1117. doi: 10.1080/1065657X.2012.10737016.

14. Amouei A, Asgharnia H, Khodadi A. Study of compost quality from rural solid wastes (Babol, Iran). J Mazandaran Univ Med Sci 2010; 19(74): 55-61. [In Persian].

15. Zazouli MA, Bagheri Ardebilian M, Ghahramani E, Ghorbanian Alah Abad M. Principles of Compost Production Technology. Tehran: Khaniran; 2018. [In Persian].

16. Schaefer M, Juliane F. The influence of earthworms and organic additives on the biodegradation of oil contaminated soil. Applied Soil Ecology 2007; 36(1): 53-62. doi: 10.1016/j. apsoil.2006.11.002.

17. Takdastan A, Hosseini Panah E, Neisi A. Survey of biological wastewater sludge biocompost for organizing and disinfectingof Khuzestan Oil Field Drill Cutting. Journal of Environmental Health Engineering 2015; 3(1): 51-60. doi: 10.18869/acadpub.jehe.3.1.51. [In Persian].

18. Adenipekun CO, Ayanleye OO, Oyetunji OJ. Bioremediation of soil contaminated by spent diesel oil using Pleurotus pulmonarius Fries (Quelet) and its effects on the growth of Corchorus olitorius. Journal of Applied Biosciences 2013; 68: 5366-73. doi: 10.4314/jab.v68i0.95063.

19. Zazouli M A, Asgharnia H, Yazdani Cherati J, Ziaee Hezarjeribi H, Ahmadnezhad A. evaluation of cow manure effect as bulking agent on concentration of heavy metals in municipal sewage sludge vermicomposting. J Mazandaran Univ Med Sci 2015; 25(124): 152-69. [In Persian].

20. Jaafarzadeh Haghighi Fard N, Moradi B, Abbasi M, Alivar Babadi R, Bahrani H, Mirzaie A, et al. Feasibility study of green wastes composting with digested and dewatering sludge from municipal wastewater treatment plant in Iran. Environ. Health Eng Manag 2015; 2(3): 149-55.

21. Butt KR, Lowe CN, Frederickson J, Moffat AJ. The development of sustainable earthworm populations at Calvert landfill site, UK. Land Degradation \& Development 2004; 15(1): 27-36. doi: 10.1002/ldr.585.

22. Fazelipour M, Takdastan A, Sekhavatjou MS. Survey on chlorine application in equencing batch reactor waste 
sludge in order to sludge minimization. Asian Journal of Chemistry 2011; 23(7): 2994-8.

23. Ceccanti B, Masciandaro G, Garcia C, Macci C, Doni S. Soil bioremediation: combination of earthworms and compost for the ecological remediation of a hydrocarbon polluted soil. Water Air Soil Pollut 2006; 177: 383-97. doi: 10.1007/ s11270-006-9180-4.

24. Huang GF, Wong JW, Wu QT, Nagar BB. Effect of C/N on composting of pig manure with sawdust. Waste Manag 2004; 24(8): 805-13. doi: 10.1016/j.wasman.2004.03.011.

25. Shakir Hanna SH, Weaver RW. Earthworms survival in oil contaminated soil. J. Plant and Soil 2002; 240: 127-32. doi: 10.1023/A:1015816315477.

26. de Godoi Pereira M, Korn M, Santos BB, Ramos MG. Vermicompost for tinted organic cationic dyes retention. Water, Air, and Soil Pollution 2009; 200(1-4): 227-35. doi : 10.1007/s11270-008-9906-6.

27. Greenberg AE. Standard methods for the examination of water and wastewater. 19th ed. USA: Amer Public Health Assn 1995.

28. Dominguez J, Edwards CA, Webster M. Vermicompositing of sewage sludge: effects of bulking materials on the growth and reproduction of the earthworm eisenia andrei. Pedobiologia 2000; 44(1): 24-32. doi: 10.1078/S00314056(04)70025-6.

29. Yvan C. Stephane C. Pierre B. Experimental evidence for the role of earthworms in compacted soil regeneration based on field observations and results from a semi-field experiment. Soil Biology and Biochemistry 2009; 41(4): 711-7. doi: 10.1016/j.soilbio.2009.01.006.

30. Ekperusi OA, Aigbodion IF. Bioremediation of heavy metals and petroleum hydrocarbons in diesel contaminated soil with the earthworm: Eudrilus eugeniae. SpringerPlus 2015; 4: 540.

31. Kabelitz N, Machackova J, Imfeld G, Brennerova M, Pieper DH, Heipieper HJ, et al. Enhancement of the microbial community biomass and diversity during air sparging bioremediation of a soil highly contaminated with kerosene and BTEX. Appl Microbiol Biotechnol 2009; 82(3): 565-77. doi: 10.1007/s00253-009-1868-0.

32. Haritash AK, Kaushik CP. Biodegradation aspects of polycyclic aromatic hydrocarbons (PAHs): a review.
J Hazard Mater 2009; 169(1-3): 1-15 .doi: 10.1016/j. jhazmat.2009.03.137.

33. Ekperusil OA, Aigbodion FI. Bioremediation of petroleum hydrocarbons from crude oil contaminated soil with the earthworm: hyperiodrilus africanus. 3 Biotech 2015; 5(6): 957-65. doi: 10.1007/s13205-015-0298-1.

34. Hosseini Panah E, Takdastan A. Feasibility of total petroleum hydrocarbon removal from drill utting with digested sludge using earth worm . J Mazandaran Univ Med Sci 2016, 25(133): 319-24. [In Persian].

35. Amouei A, Fallah H, Asgharnia H, Mousapour A, Parsian $\mathrm{H}$, Hajiahmadi $\mathrm{M}$, et al. Comparison of heavy metals contamination and ecological risk between soils enriched with compost and chemical fertilizers in the North of Iran and ecological risk assessment. Environmental Health Engineering and Management Journal. 2020;7(1):7-14. doi:10.34172/EHEM.2020.02

36. Opuada Ameh A, Mohammed-Dabo IA, Ibrahim S, Ameh JB, Tanimu Y, Kolawole Bello T. Effect of earthworm inoculation on the bioremediation of used engine oil contaminated soil. Int. J. Biol. Chem. Sci 2012; 6(1): 493503. doi: 10.4314/ijbcs.v6i1.44

37. Sinha R, Chandran V, Soni B, Patel U, Ghosh A. Earthworms: nature's chemical managers and detoxifying agents in the environment: an innovative study on treatment of toxic wastewaters from the petroleum industry by vermifiltration technology. Environmentalist 2012; 32(4):445-52. .doi: 10.1007/s10669-012-9409-2.

38. Kardani M, Takdastan A. Removal of total petroleum hydrocarbons using vetiveria zizanioides and microbial population changes in soil contaminated with oil in Ahvaz. Journal of Mazandaran University of Medical Science 2015; 25(131): 87-97. [In Persian].

39. Hickman ZA, Reid BJ. Earthworm assisted bioremediation of organic contaminants. Environ Int 2008; 34(7): 1072-81. doi: 10.1016/j.envint.2008.02.013.

40. Ameh A, Mohammed-Dabo IA, Ibrahim S, Ameh JB, Azienge CD, Taninu Y. Earthworm survival in used engine oil contaminated soil spiked with manure. International Journal of Biological \&Chemical Sciences 2011; 5(3): 92329. doi: 10.4314/ijbcs.v5i3.72177. 